African Crop Science Journal by African Crop Science Society is licensed under a Creative Commons Attribution 3.0 Uganda License. Based on a work at www.ajol.info/ and www.bioline.org.br/cs DOI: https://dx.doi.org/10.4314/acsj.v28i3.10

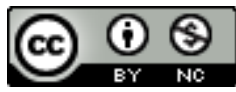

\title{
EFFECT OF PLANT EXTRACTS ON RADIAL GROWTH OF Helminthosporium oryzae CAUSATIVE OF BROWN SPOT DISEASE OF RICE UNDER IN-VITRO
}

\author{
C.C. IWUAGWU, C.C. ONONUJU'2, C.I. UMECHURUBA ${ }^{1}$, A.C. NWOGBAGA ${ }^{2}$, \\ A.E. OBIDIEBUBE, H. OKOLIE, C.C. OBASI and A.O. UWAOMA \\ Department of Crop Science and Horticulture, Nnamdi Azikiwe University, Awka Anambra State, \\ Nigeria \\ ${ }^{1}$ Department of Plant Health Management, Michael Okpara University of Agriculture, \\ Umudike, Abia State, Nigeria \\ ${ }^{2}$ Department of Crop Production and Landscape Management Ebonyi State University, \\ Abakaliki, Nigeria \\ Corresponding author: chrisiwuag@yahoo.com
}

(Received 27 May 2020; accepted 31 August 2020)

\begin{abstract}
Brown spot disease, caused by Helminthosporium oryzae, is worldwide problem capable of causing considerable damage to paddy in the nursery, field or grain yield. The disease is seed borne, and thus can be transmitted through infected seeds and crop residues, alternate hosts and contaminated irrigation water. The objective of this study was to evaluate the effect of plant extracts on radial growth of Helminthosporium oryzae on rice plants. An in-vitro experiment was conducted at the Plant Pathology Laboratory of National Root Crop Research Institute, Umudike, Abia State, in Nigeria. Treatments included water and alcohol extracts of Azardiractha indica (Neem leaves), Piper guinensis (seeds), Garcinia cola (Bitter cola seeds), Ocimum gratissimum (leaf) and Vernonia amygdalina (leaf); and synthetic fungicide (Benomyl) at a concentrations of 10,25 and 30\% of the extract applied to $H$. oryzae in culture. The test materials were administered on Helminthosporium oryzae, sourced from rice seeds and infected shoot system of rice. Alcohol extract of Piper guineensis had the highest radial growth inhibition (89.89\%) by the fifth day, but was not significantly different from Azardiractha indica, which had an inhibition value of $81.02 \%$. The least effective plant extract was Ocimum gratssimum with radial inhibition of $11.50 \%$, which occurred also on the fifth day. Plant extracts were as effective as the synthetic fungicide in inhibiting growth of the test fungus. Therefore, the effective extracts, all of which are readily available to the farmers, should be promoted instead of the synthetic fungicides, which are in limited supply and invariably expensive for rice farmers in Nigeria.
\end{abstract}

Key Words: Helminthosporium oryzae, Piper guineensis, Zinzigiber officinale 
La maladie des taches brunes, causée par Helminthosporium oryzae, est un problème mondial susceptible de causer des dommages considérables au riz en pépinière, champ et en rendement en grains. La maladie est transmise par les semences et peut donc être transmise par des semences et des résidus de culture infectés, des hôtes alternatifs et de l'eau d'irrigation contaminée. L'objectif de cette étude était d'évaluer l'effet d'extraits de plantes sur la croissance radiale d'Helminthosporium oryzae sur les plants de riz. Une expérience in vitro a été menée au laboratoire de phytopathologie de l'Institut national de recherche sur les cultures racines, Umudike, État d'Abia, au Nigéria. Les traitements comprenaient des extraits aqueux et alcooliques d'Azardiractha indica (feuilles de Neem), de Piper guinensis (graines), de Garcinia cola (graines de cola amer), d'Ocimum gratissimum (feuille) et de Vernonia amygdalina (feuille); et fongicide synthétique (Benomyl) à des concentrations de 10, 25 et $30 \%$ de l'extrait appliqué sur H. oryzae en culture. Les matériaux d'essai ont été administrés sur Helminthosporium oryzae, provenant de graines de riz et d'un système de pousses de riz infecté. L'extrait alcoolique de Piper guineensis avait l'inhibition de la croissance radiale la plus élevée (89,89\%) au cinquième jour, mais n'était pas significativement différente de celle d'Azardiractha indica, qui avait une valeur d'inhibition de $81,02 \%$. L'extrait de plante le moins efficace était Ocimum gratssimum avec une inhibition radiale de $11,50 \%$, qui s'est également produite le cinquième jour. Les extraits végétaux étaient aussi efficaces que le fongicide synthétique pour inhiber la croissance du champignon d'essai. Par conséquent, les extraits efficaces, qui sont tous facilement disponibles pour les agriculteurs, devraient être encouragés à la place des fongicides synthétiques, qui sont en quantité limitée et invariablement coûteux pour les riziculteurs au Nigeria.

Mots Clés: Helminthosporium oryzae, Piper guineensis, Zinzigiber officinale

\section{INTRODUCTION}

The key disease to viable rice production in Nigeria is Brown spot disease, caused by Helminthosporium oryzae (Grist, 1975; Imolehin, 1983; Ekeleme et al; 2008). It is distributed world wide and causes considerable damage to paddy rice in nurseries, field and shrinkage of grain yield. The disease is seed borne and is thus transmitted to healthy crops through infected seeds and crop residues, alternate hosts and contaminated irrigation water (Samson and Kadiri,. 2007).

Unlike other fungal diseases of rice, Brown leaf spot is more severe on older plants than on seedlings; and is characterised by dark brown oval spots (about $3.8 \mathrm{~cm}$ long) on the leaves (Grist, 1975). The larger spots usually have lighter coloured centres and dark brown margins. Cultural control measures include burning all crop residues and alternative hosts and use of seeds from healthy plants (Aquino et al., 1985).
Application of chemicals such as Seedplus, Dress force, Apron star or Super Homai at the rate of $10 \mathrm{~g}$ per $5 \mathrm{~kg}$ of seeds before sowing has been effective in controlling this seed borne pathogens (Groth and Hollier, 2000, NCRI,2008). When symptoms are observed, Ekeleme et al. (2008) recommended a spray of Dithane M-45 (Mancozeb) weekly at the rate of $1.5 \mathrm{~kg} \mathrm{ha}^{-1}$ (about 2-3 small match boxes full per $15 \mathrm{~L}$ sprayer) for 3 weeks as an effective control measure. The objective of this study was to evaluate the effect of plant extracts on radial growth inhibition of Helminthosporium oryzae on rice plants as an alternative to synthetic fungicides.

\section{MATERIALS AND METHODS}

Preparation of plant extracts. Extract were prepared from fresh leaves of Azardiractha indica (Neem leaves), Piper guinensis (seeds), Garcinia cola (Bitter cola seeds), Ocimum gratissimum (leaf) and Vernonia amygdalina 
Radial growth of Helminthosporium oryzae causal organism of Brown spot disease 475

(leaf), using sterile distilled water and absolute alcohol of $98 \%$ purity. The leaves or seeds in their respective cases, were thoroughly washed in running tap water, and subsequently with distilled water, before being air dried at $27^{\circ} \mathrm{C}$ for twelve hours. The materials, which were not completely dried were smashed using a warring blender to obtain approximately 1 $\mathrm{kg}$ of paste of each test material.

Water extraction. Water extracts were obtained by adding 10, 25 and $30 \mathrm{~g}$ of each paste to $100 \mathrm{ml}$ of sterile distilled water in 250 $\mathrm{ml}$ beakers; and stirring vigorously before allowing to stand for 1 hour. Each plant material was extracted separately, with intermittent cleaning of the warring blender using sterile distilled water. The supernatant liquid of each extract was passed through a Whatman No 1 filter paper. The filtrate was also passed through a membrane filter $(0.22 \mathrm{~cm})$ to avoid bacterial or fungal contamination. The resulting filtrate was later concentrated by autoclaving and allowed to cool to room temperature, before being stored under aseptic refrigerator conditions, in properly corked and labelled Mac Carthney bottles. The interface between the corks and the bottles were sealed with masking tapes, to prevent contamination.

Alcohol extraction. For alcohol extraction, each plant material was oven dried at $45^{\circ} \mathrm{C}$ in for 24 hours after being washed three times with distilled sterile water, and air-dried at room temperature. Each plant material was ground with a warring blender to obtain approximately $1 \mathrm{~kg}$ powder each. Each powder of 10, 25 and $30 \mathrm{~g}$ was extracted with $95 \%$ ethanol (100 $\mathrm{ml}$ ) and concentrated through a rotary vacuum pump flash evaporator, to syrup form weighing $26 \mathrm{~g}$ from each powder. The syrup residue obtained was diluted to $2.5 \mathrm{~g} \mathrm{l}^{-1}$. Preparations were made in triplicates throughout the experiment.

Growth of Helminthosporium oryzae. One disc (3 mm diameter) of an 8 day-old culture of each fungus was placed in each of three petri dishes ( $9 \mathrm{~cm}$ diameter) containing $20 \mathrm{ml}$ of potato dextrose agar (PDA) medium and 3 $\mathrm{ml}$ of leaf extract (Amadioha, 2003). Three concentrations of the extracts were tested, namely 10,25 and $30 \mathrm{~g}$ of each powder to $100 \mathrm{ml}$ of absolute (98\%) alcohol and 0 (sterile water) as control. Each of these concentrations was replicated three times. These were tested on the radial growth of three fungal pathogens, namely, Fusarium moniliforme, Heminthosporium spp and Phoma spp; each fungus was tested separately. Sterile distilled water was used as the control. Twelve Petri dishes were used for each plant extract, against one fungus at a time. Another twelve dishes were used for the synthetic fungicides at concentrations of 10, 25 and 30 $\mathrm{g}$ per $100 \mathrm{ml}$ of distilled water. Each concentration was replicated three time with distilled water as control; and laid out in a randomised complete design (CRD). The whole set up of Petri dishes was incubated at $27^{\circ} \mathrm{C}$, with 12 hours of alternating light and darkness.

Determination of radial growth. Radial growth of the test fungi was measured daily for a period of seven days starting from the second day after inoculation. The diameter of the fungal colony was measured from the back sides of the plates, using a metre rule. Colony growth was measured by taking the average of the largest and shortest diameter of the same colony per plate. This was because colony growth of fungi was not always in regular circles. The fungitoxicity of the extracts was calculated in terms of percentage colony inhibition using the formula of Amadioha (2003):

Growth inhibition $(\%)=\frac{\mathrm{dc}-\mathrm{dt}}{\mathrm{dc}} \times \frac{100}{1}$

Where:

dc is the average diameter of fungal colony with control; and dt is the average diameter of fungal colony with treatment. 
Data analysis. Data collected were subjected to Analysis of Variance (ANOVA) using GenStat 7.2 DE version (2007). Mean separation was done using Fisher's Least Significant Difference (F-LSD) at 5\% level of probability.

\section{RESULTS}

Radial growth of Helminthosporium oryzae. There were significant negative radial growth effects of plant extracts of both aqueous and alcohol extraction, on radial growth of Helminthosporium oryzae in culture (Table 1). Zinzigiber officinale extracts in alcohol had the highest radial growth inhibition effect (94.96\%), but was not significantly different from the effect of Azardiractha indica, which had inhibition value of $92.07 \%$. The lowest growth inhibition was in O.gratssimum, by aqueous extraction method, which had radial inhibition of $16.50 \%$ right on the first day. On the second day, alcohol extract of Piper guinensis had the highest (86.30\%) inhibition value; followed by alcohol extract of $Z$. officinale $(82.30 \%)$. The least effect was in aqueous of G. cola with inhibition value of $16.60 \%$.

On the third day, alcohol extract of Piper guinensis had the highest inhibition value of $89.89 \%$; followed by alcohol extract of Azardiractha indica $(81.02 \%)$. The least effect in this case was in aqueous extract of $O$. gratssimum with value of $11.50 \%$. The five plant extracts by both water and alcohol extractions performed better than the control.

Interaction effects of plant extracts $x$ concentrations. For Bitter cola, there was significant interaction effect among the three concentrations $\mathrm{x}$ plant extract combinations (Table 1). In alcohol, the highest reduction was $92.52 \%$ obtained in $30 \mathrm{~g}$ of the extract on the first day. This was followed by $86.70 \%$ achieved with $30 \mathrm{~g}$ of the extract by alcohol extraction on the third day. The lowest values were obtained in water extraction.
For Neem, the interaction effect of plant extract $\times 10 \mathrm{~g}$ by alcohol extraction, gave comparatively the highest radial inhibition on third $(90.60 \%)$ and fifth $(85.41 \%)$ days in culture, compared to plant extract x $25 \mathrm{~g}$ and plant extract x $30 \mathrm{~g}$ interaction effects. It was also observed in Neem that the inhibition effect depreciated with time as higher radial inhibitions were observed in the first day $(95.40 \%)$ than in subsequent days (Table 1). This trend was observed in $Z$. officinale, but was different in $O$. gratssimum and $P$. guinensis, where positive interaction effects were observed with increase in concentration of plant extracts.

Compared to the standard fungicide (Benlate), it was clear that phytochemical effects due to alcohol extraction performed better for all the plant materials used; except for O.gratssimum in which radial growth was inhibited more by the action of the synthetic fungicide.

\section{DISCUSSION}

Effects of plant extracts on radial growth of Helminthosporium oryzae in culture. The study showed that the various plant extracts and the synthetic fungicide inhibited the radial growth of Helminthosporium oryzae in culture. Piper guineesis was found to perform best in suppressing mycelial growth of $H$. oryzae; followed by Azadirachta indica; while the least was Occimum gratissimum. The significant differential effect of the various plant materials could be as a result of the different bioactive components of each botanic extract. According to Amadioha (2003), the active agent in A. indica is Azadiratin; while those in $Z$. officinale consist of linalole, imonene, Zingerene and Linoelic acid. In Garcinia cola, the active ingredients responsible for antimicrobial, anti-viral and anti-inflammatory properties are bioflavanoids, xanthenes and benzophenomes (Kikuzaki and Nakatani, 1993; Derbalah, 2011). According to them, some of these compounds like polyphenols have been 
TABLE 1. Percentage growth inhibition of Helninthosporum oryzae by the treatments in first, third and fifth days

\begin{tabular}{|c|c|c|c|c|c|c|c|c|c|c|c|c|c|c|c|}
\hline \multirow[t]{3}{*}{ Treatment } & \multicolumn{14}{|c|}{ Incubation period (days), Concentration (\%) and growth inhibition (\%) } & \multirow[b]{3}{*}{ Mean } \\
\hline & \multicolumn{5}{|c|}{1 day } & \multicolumn{5}{|c|}{3 days } & \multicolumn{4}{|c|}{5 days } & \\
\hline & 0 & 10 & 25 & 30 & Mean & 0 & 10 & 25 & 30 & Mean & 0 & 10 & 25 & 30 & \\
\hline \multicolumn{16}{|l|}{ Garcinia cola } \\
\hline Water extract (WE) & 0 & 35.70 & 38.10 & 34.00 & 27.00 & 0 & 15.40 & 24.70 & 26.20 & 16.60 & 0 & 28.90 & 29.60 & 33.50 & 23.00 \\
\hline Alcohol extract (AE) & 0 & 53.27 & 39.26 & 92.52 & 71.51 & 0 & 28.20 & 36.50 & 86.70 & 63.20 & 0 & 43.84 & 26.29 & 75.39 & 61.62 \\
\hline \multicolumn{16}{|l|}{ Azardiractha indica } \\
\hline Water extract & 0 & 61.50 & 68.90 & 68.90 & 49.80 & 0 & 61.40 & 69.10 & 72.70 & 50.80 & 0 & 68.00 & 58.10 & 83.10 & 52,30 \\
\hline Alcohol extract & 0 & 95.40 & 95.41 & 76.47 & 92.07 & 0 & 90.60 & 68.80 & 60.75 & 67.31 & 0 & 85.41 & 71.00 & 66.18 & 81.02 \\
\hline \multicolumn{16}{|l|}{ Zingiber oficinale } \\
\hline Water extract & 0 & 44.90 & 25.20 & 34.20 & 26.10 & 0 & 31.00 & 25.30 & 32.00 & 22.10 & 0 & 27.10 & 18.50 & 23.60 & 17.30 \\
\hline Alcohol extract & 0 & 95.09 & 95.09 & 88.66 & 94.96 & 0 & 86.20 & 86.20 & 56.90 & 82.30 & 0 & 47.50 & 57.65 & 55.23 & 65.33 \\
\hline \multicolumn{16}{|l|}{ Ocimum gratissimum } \\
\hline Water extract & 0 & 21.60 & 21.40 & 23.00 & 16.50 & 0 & 31.00 & 22.30 & 25.40 & 19.70 & 0 & 2.20 & 25.50 & 18.30 & 11.50 \\
\hline Alcohol extract & 0 & 19.47 & 13.79 & 94.83 & 57.02 & 0 & 36.10 & 68.30 & 76.30 & 70.20 & 0 & 24.79 & 63.18 & 69.42 & 64.72 \\
\hline \multicolumn{16}{|l|}{ Piper guinensis } \\
\hline Water extract & 0 & 33.30 & 22.20 & 33.30 & 22.20 & 0 & 24.30 & 33.10 & 33.70 & 22.80 & 0 & 16.20 & 20.50 & 21.70 & 14.60 \\
\hline Alcohol extract & 0 & 70.35 & 95.15 & 95.15 & 90.42 & 0 & 67.90 & 89.30 & 88.10 & 86.30 & 0 & 72.95 & 93.24 & 91.88 & 89.89 \\
\hline Benlate & 0 & 65.00 & 62.80 & 56.10 & 46.00 & 0 & 57.40 & 67.30 & 66.20 & 47.70 & 0 & 34.80 & 51.70 & 51.90 & 34.60 \\
\hline LSD $0.05(\mathrm{WE})$ & & 1.39 & & & 0.69 & & 1.57 & & & 0.78 & & 2.41 & & & 1.71 \\
\hline LSD 0.05 (AE \& Benlate) & & 17.95 & & & 8.98 & & 23.90 & & & 11.95 & & 22.85 & & & 11.42 \\
\hline
\end{tabular}


shown to express their antifiungal action through membrane perturbations. This disruption of the cell membrane, coupled with the actions of lysolitic compounds on the transpeptidation of the cell membrane, could lead to enhanced antimicrobial effect of the biocompounds. Opara and Agugo (2014) also observed that hot water extract of $P$. guinensis had better performance than $Z$. officinale in inhibiting growth of bacteria that caused postharvest loss of tomato in Abia State, Nigeria.

Effect of concentrations of bioactive compounds of the plant extracts on radial growth of Helminthosporium oryzae in culture. The fungitoxicity of the plant extracts against mycelial growth increased as the concentration increased in the plant extracts. This is in agreement with Bailen et al. (2013), who reported that the mortality of $B$. brassicae using plant extracts, increased with increasing concentrations and exposure periods. According to them, the physical and chemical properties of the essential oils exhibited different persistent levels of pesticide properties and different action mechanisms. Suleiman and Taiga (2009) reported that the crude extract of $G$. cola fruits showed significant reduction in mycelial growth of Pythium aphanidermatum at different levels of concentrations, which is in agreement with the result of this study. According to them, high fungi toxicity in -vitro was observed at 80 and $100 \%$ concentrations.

Effect of differences in extracting solvents on inhibitory activities of the plants bioactive compounds. Alcohol extracts had higher inhibition effects than the aqueous counterparts (Table 1). This could be as a result of higher solvent and extractability of alcohol of phytochemical substances used in the study, compared to water extraction. This was observed in all the plant phytochemicals used. This is in agreement with the findings of Ngo et al. (2017) in a study on the 'impact of different extraction solvents on bioactive compounds and antioxidant capacity from the root of Salacia chinensis L.', where they observed that absolute methanol had the highest extractable solids (15.6\%), followed by $50 \%$ ethanol, $50 \%$ methanol, and $50 \%$ acetone $(14.3 \%, 12.3 \%$, and $12.2 \%$, resp.). They also reported that water extracted half of extractable solids in comparison with absolute methanol.

Interaction effects of plant extracts and
concentration of bioactive phytochemicals. Interaction effects of plant bioactive compounds and concentration showed that there was significant inhibitory effects on radial growth of the test fungus (Table 1). It was also observed in $O$. gratssimum by alcohol extraction that the inhibition effect appreciated with time as lower mean radial inhibitions were observed in the first day $(19.47 \%)$ than in subsequent days. This could mean that the actions of the bioactive compounds of the various botanicals were more effective with concentration and time of exposure on the target organism. This is consonance with the findings of Ahmed et al. (2020), who in their study 'insecticidal activity and biochemical composition of Citrullus colocynthis, Cannabis indica and Artemisia argyi extracts against cabbage aphid (Brevicoryne brassicae L.)', reported that the percent mortality of $B$. brassicae to be directly related to the concentration of the plant extracts and the exposure period. According to them, maximum mortality was recorded after $72 \mathrm{hr}$ of exposure to the $A$. argyi extract at a concentration of $20 \mathrm{mg} \mathrm{mL}^{-1}$ and caused $88.33 \pm 3.87 \%$ mortality; while after $48 \mathrm{hr}$ of exposure, the mortality was recorded as $60.00 \pm 2.27 \%$. Depreciation in inhibitory effects of the active ingredients was noticed in Neem by alcohol extraction. This might have been caused by negative effects of some environmental factors such as heat which might have led to increased breakdown of the fungitoxic substances in the plant extracts. Also, the decrease in fungitoxic effect of the 
Radial growth of Helminthosporium oryzae causal organism of Brown spot disease 479

bioactive substance with time experienced in Neem plant extract might have been as a result of reaction of these active substances with some atmospheric chemical elements, thereby resulting to less fungitoxic compounds.

The oxidation of phenolic compounds using oxygen and formic acid as indirect oxidants (Javier, et al., 2014). According to them, this novel immobilised tri-enzyme system removes important pollutants such as hydroxylated aromatic derivatives (phenol, 4-aminophenol, 2,4-dichloro-phenol or á-naphthol) using formic acid and molecular oxygen as substrates. In addition, this system generates $\mathrm{CO}_{2}$ as waste beyond the oxidised phenols that can be easily separated from the aqueous solution. Also, Alnaizy and Akgerman (2000) reported in their experiment 'Advanced oxidation of Phenolic compounds' that Phenol degradation with a $\mathrm{UV} / \mathrm{H}_{2} \mathrm{O}_{2}$ advanced oxidation process gave the reaction products which included hydroquinones, benzoquinones, and aliphatic carboxylic acids with up to six carbon atoms which do not have the same bioactivity with those that were not oxidised.

\section{ACKNOWLEDGEMENT}

The authors appreciate the Laboratory technicians in the Plant Pathology Laboratory of National Root Crop Research Institute (NRCRI), Umudike, Abia State, in Nigeria for their technical assistance in the course of this research work.

\section{REFERENCES}

Amadioha, A. 2003. Evaluation of some plant leaf extracts against colletotrichum lindemuthianum in cowpea. Acta Phytopathologica et Entomologica Hungarica 38:259-265.

Ahmed, M., Peiwen, Q., Gu, Z., Liu, Y., Sikandar, A., Hussain, D., Javeed, A., Shafi, J., Iqbal, N.F., An, R., Guo, H., Du, Y., Wang, W., Zhang,Y. and Ji, M.
2020. Insecticidal activity and biochemical composition of Citrullus colocynthis, Cannabis indica and Artemisia argyi extracts against cabbage aphid (Brevicoryne brassicae L.). Scientific Reports 10(1):1-10.

Alnaizy, R. and Akgerman, A. 2000. Advanced oxidation of phenolic compounds. Advances in Environmental Research 4(3):233-244.

Aquino, G.B., Minnick, R.S. and Heinrichs, E.A. 1985. Integrated rice pest management. Training course. A manual of performance objective IRRI, Philppines. pp. 156-173.

Bailen, M. Julio,LF, Diaz,C E,Sanz, J, Martinez-Diaz, R.A, Cabrera, R, Burillo, J. and Gonzales-Coloma, A. 2013. Chemical composition and biological effects of essential oils from Artemisia absinthium L. cultivated under different environmental conditions. Industrial Crops and Products 49:102-107.

Derbalah, A., El-Mahrouk, M. and El-Sayed, A. 2011. Efficacy and safety of some plant extracts against tomato early blight disease caused by Alternaria solani. Plant Pathology Journal (Faisalabad) 10:115121.

Ekeleme, F., Kamara, A.Y, Omoigui, L.O., Tegbaru, A., Mishelia, J. and Onyibe, J.E. 2008. Guide to rice production in Bornu State, Nigeria. IITA. WWW.IIta.org pp. 130.

Grist, D. 1983. Rice, Tropical Agriculture Series. Longman, London. 548pp.

Groth, D. and Hollier, M. 2000. Rice diseases: Plant pathology and crop physiology Department, Louisiana State University, USA. pp.1-10.

Imolehin, E. 1983. Rice seedborne fungi and their effect on seed germination. Plant Disease 67:1334-1336.

Javier, R.M., Susana, V.L., José, M.G., and Fernando, L.G. 2014. Oxidation of phenolic compounds catalyzed by immobilized multi-enzyme systems with 
integrated hydrogen peroxide production. Journal of Green Chemistry 16(1):303322.

Kikuzaki, H. and Nakatani, N. 1993. Antioxidant effects of some ginger constituents. Journal of Food Science 58: 1407-1410.

NCRI. 2008. Training workshop. Manual on rice production and processing. National Cereal Research Institute Badeggi, Bida, Niger States, Nigeria. pp. 20- 74.

Ngo, T.V., Scarlett, C.J., Bowyer, M.C., Ngo, P.D. and Vuong, Q.V. 2017. Impact of different extraction solvents on bioactive compounds and antioxidant capacity from the root of Salacia chinensis L. Journal of Food Quality 2017:1-8.

Okereke, V.C. and Wokocha, R.C. 2006. Invitro growth of fours isolates of slerotium rolfsii sacc in the humid tropics. African Journal of Biotechnology 6(16):187-1881.

Opara, E. and Agugo, B. 2014. Application of organic amendments and botanical foliar sprays against bacterial diseases of mungbean (Vigna radiata L.) in South Eastern Nigeria. Greener Journal of Agricultural Sciences 4:052-057.

Samson, I.O. and Kadiri, M.A. 2007. Problems and prospect of rice production in central district of Edo State. Journal of Human Ecology 22(2):123-128.

Suleiman, M.N. and Taiga, A. 2009. Efficacy of aquenous extracts of neem and sharf from the control of fungi associated with milled and unmilled store rice grain. Proceeding of the $5^{\text {th }}$ Akure - Humboldt Ellog/Saat Annual Conference. pp. 71 73. 